Mediterranean Journal of Humanities mjh.akdeniz.edu.tr I/2, 2011, 163-170

\title{
The Effects of Vocabulary Strategy Training on Vocabulary Learning and Autonomy: A Case Study of Turkish EFL Students
}

\author{
Kelime Strateji Ĕ̆gitiminin Kelime Ö̆̆renimi ve Özerkliği Üzerindeki Etkileri: \\ Yabancı Dil Olarak İngilizce Öğrenen Türk Öğrenciler ile Yapılan Bir Durum \\ Incelemesi
}

\author{
Yeşim NALKESEN * \\ Yeşim ÖZEK ${ }^{* *}$
}

\begin{abstract}
Use of language learning strategies can play a very important role on the way to gain success and learner autonomy in language learning. They can be more powerful learning tools provided that they are chosen properly according to the situations language learners will be faced with. For learners' to receive strategy training is very important in helping them with tackling the language situations they will encounter. Use of learning strategies serves as an effective way for learners to overcome such difficulties. According to Willliams and Burden (1997), use of appropriate language learning strategies has a vital contribution to make to language learning success, which underlines the significance of the incorporation of strategy training in teaching a foreign language. The present study had two main purposes. Firstly, it aimed to investigate the effects of vocabulary strategy training on vocabulary learning and, secondly, it aimed to investigate the effects of vocabulary strategy training on learner autonomy at intermediate level in the preparatory classes of a foundation university.
\end{abstract}

Keywords: Strategy training, learner autonomy, vocabulary learning

Özet: Yabancı dil öğrenme stratejilerinin kullanımı, öğrencilerin başarıya ulaşmasında ve özerkliğe kavuşmasında önemli bir rol oynayabilir. Bu stratejiler, öğrencilerin karşılaşacakları durumlara uygun bir biçimde doğru olarak seçilirse çok daha etkili olan dil öğrenme araçları haline gelebilir. Öğrencilerinin strateji eğitimi alması, dil öğrenimi sırasında karşılaşacakları çeşitli zor durumlarla baş edebilmelerini sağlaması açısından önem arz etmektedir. Öğrenme stratejilerinin kullanımı öğrencilerin söz konusu zorluklarla baş edebilmeleri açısından etkili bir yöntemdir. Williams ve Burden (1997) uygun dil öğrenim strateji kullanımının dil öğrenimi başarısına ciddi bir katkısı olduğunu belirtmektedir; bu da öğrencilere strateji eğitiminin verilmesi konusunun öneminin altını çizmektedir. Bu çalışmanın iki amacı bulunmaktadır: Birincisi, kelime strateji eğitiminin, İngilizceleri orta seviye olarak tespit edilmiş üniversite hazırlık sınıfi öğrencilerinin kelime öğrenimi üzerindeki etkisini incelemek, ikincisi, kelime strateji eğitiminin kelime öğrenimi özerkliği üzerindeki etkilerini incelemektir.

Anahtar Sözcükler: Strateji eğitimi, öğrenim özerkliği, kelime öğrenimi

\section{Introduction}

Over the past few decades, there has been a growing interest and emphasis upon a learner centred classroom, which led to an inevitable increase in research dedicated to finding insights concerning the use and impact of language learning strategies (Cohen, \& Aphek, 1981; Wenden,

\footnotetext{
* Lecturer, EFL Department, Işık University, ynalkesen@gmail.com

** Assist. Prof., Northern Arizona University, yesimzk@gmail.com
} 
\& Rubin, 1987; O’Malley, \& Chamot, 1990; Ellis, 1994; Schmitt, 1997; Marefat, \& Shirazi, 2003 and a number of others). The shift from a teacher based classroom to a learner based classroom with more emphasis on learners and learning is the natural consequence of the notion that values the significance of learners' engagement in the learning environment; and of the changes in the curriculum towards a more learner centred method of teaching (Thanasoulas, 2000).

In a learner centred method of teaching, students' use of strategies plays a very important role in the learning process at all language levels. Learners who seek for support to learn 'how to fish' can fend for themselves when they encounter obstacles during this process such as keeping the words in their memory, making associations, producing them and so on. The use of learning strategies serves as an effective way for learners to overcome such difficulties.

The use of vocabulary strategies in learning words has been regarded as playing a prominent role by various theorists and researchers in the field (Oxford, 1990; Nation, 1990; Schmitt, 1997; Williams, \& Burden, 1997). Vocabulary strategy instruction seems to be very important in equipping the students with the necessary strategies to expand their knowledge of vocabulary instead of giving the students only specific words to learn (Hulstjin, 1993; cited in Ghazal, 2007).

Strategy training aims to provide learners with awareness of language learning strategies through instruction (Cohen, 2003). The most efficient way to provide learner awareness is through explicit instruction. Strategy training has the following benefits for language learners (Cohen, 2003). Strategy training helps the language learners to:

a) self-diagnose their strengths and weaknesses in language learning;

b) become aware of what helps them to learn the target language most efficiently;

c) develop a broad range of problem-solving skills;

d) experiment with familiar and unfamiliar learning strategies;

e) make decisions about how to approach a language task;

f) monitor and self-evaluate their performance;

g) transfer successful strategies to new learning contexts.

Taking the positive outcomes of strategy training into consideration, it is important to teach language learning strategies to language learners. Learners' control over their learning processes and the learners' consciousness of their own learning may lead to a better and more autonomous method of learning.

\section{The Effects of Learning Strategies and Strategy Training on Learner Autonomy}

Learners' making use of language learning strategies is a key step in gaining autonomy as they will understand and evaluate their own learning process and will be able to exert some control over these processes, which will result in their becoming more responsible for their own learning and taking charge of their own learning. Learning strategies are important cornerstones on the path to autonomy. As Holec (1981) and Little (1991) put it, learners cannot feel responsible for their own learning process, in other words cannot be autonomous, unless they have ideas of what, why and how they are learning. Learners need to receive training in order to use strategies effectively and appropriately, as simply knowing a strategy does not guarantee that the student will employ that strategy, or will be able to use it effectively (Vann, \& Abraham, 1990, 192). Wenden (1991) claims that strategy training needs to be incorporated into the curriculum to foster learner autonomy and therefore it is highly important to investigate the effects of strategy training upon learning autonomy. Vocabulary learning autonomy plays a prominent role in vocabulary learning and therefore the importance of strategy training to promote learner autonomy 
should not be neglected by the educational authorities, instructors and curriculum designers.

Various researches support the idea that teaching students how to use different language learning strategies contributes to their language ability (Rubin, 1975; Oxford, 1990; O’Malley, \& Chamot, 1990; Wenden, 1991 and a number of others). Oxford (1990) states that "language learning strategies are important for language learning because they are tools for active, selfdirected involvement, which is essential for developing communicative competence". Use of language learning strategies assists students in the process of becoming more independent and confident learners.

The purpose of the present study is to investigate the effects of vocabulary strategy training on vocabulary learning achievement and the learner autonomy of the students who are at intermediate level in the preparatory class of a foundation university. The participating students in the experimental group were given strategy training by the researcher; the students in the control group received no special treatment as the present study is of an experimental design.

Quantitative and qualitative analysis were used in order to analyze these two purposes. The comparison between the pre and post vocabulary tests, pre and post interview results and think aloud protocol results helped to establish the effects of vocabulary strategy training on vocabulary learning achievement.

The comparison between the pre and post learner autonomy questionnaires, post interview results, on the other hand, helped to determine the effects of vocabulary strategy training on learner autonomy.

The following specific questions were addressed in the present study:

- Are there any effects of vocabulary strategy training upon vocabulary learning? If so, how?

- Are there any effects of vocabulary strategy training upon vocabulary learning autonomy? If so, how?

\section{Methodology}

The present study was conducted at Yeditepe University during the second term of 2009-2010. The data was collected in two preparatory classes which were at intermediate level. 20 students participated in the present study. These participants were learning English at preparatory school in a private university; they needed English to pursue their academic studies. Their ages were between 17 and 20. Their English level was diagnosed as intermediate based on the test administered by the university. A multi method approach was used in the present study in order to strengthen the reliability of the results with a comprehensive multidimensional perspective (Foster, 1997). Stratified purposeful sampling was done in the present study as the researcher intended to investigate the effects of the treatment (vocabulary strategy training) in two groups. A multi-method approach was used in order to collect data. Five instruments were employed to answer the research questions: a) Schmitt's Taxonomy of Vocabulary Learning Strategies (1997); b) Focus Group Interview; c) Pre and post vocabulary test; d) Learner Autonomy Questionnaire (adapted from Güven, \& Sünbül, 2007); e) Think aloud protocols.

The researcher carried out a pre interview before the actual study took place in order to gain insights on the learners' familiarity with strategy, what strategies learners use in vocabulary learning; how sufficient learners find themselves in regard to their knowledge of vocabulary; learners' expectations from the instructors in respect to vocabulary learning.

The participating students in the control and experimental groups were given a pre vocabulary test and a pre vocabulary learning autonomy questionnaire. Afterwards, the students in the experimental group received a vocabulary strategy training for 3 weeks. The students in the 
control group did not receive special treatment in this phase. Every week, the researcher conducted a think-aloud cloud protocol session with the students in the experimental group in order to find out whether they recalled the target lexical items taught in the vocabulary strategy training; and what strategies they employed in order to recall these items.

One week after the completion of the vocabulary strategy training, students in the experimental and the control groups were given a post vocabulary test and a post vocabulary learning autonomy questionnaire in order to measure the effects of vocabulary strategy training on vocabulary learning and learner autonomy. The quantitative data obtained from the learner autonomy questionnaires and vocabulary tests were analyzed by means of the Wilcoxon Signed Ranks Test and the Mann Whitney $U$ test. The qualitative data obtained from the pre interview and think aloud protocols results were analyzed by means of pattern coding.

Table 1. Overview of the research questions, instruments and data analysis

\begin{tabular}{|c|c|c|}
\hline Research Questions & Instruments & ata Analysis \\
\hline $\begin{array}{l}\text { Are there any effects of } \\
\text { vocabulary strategy } \\
\text { training on vocabulary } \\
\text { learning? If so, how? }\end{array}$ & $\begin{array}{l}\text { (1) Schmitt's Taxonomy of } \\
\text { Vocabulary Learning Strategies } \\
\text { (1997); } \\
\text { (2) Pre and Post Focus Group } \\
\text { Interviews; } \\
\text { (3) Think Aloud Protocol Sessions; } \\
\text { (4) Pre and Post vocabulary tests. }\end{array}$ & $\begin{array}{l}\text { Comparative Analysis } \\
\text { Pattern Coding } \\
\text { Pattern Coding } \\
\text { Mann Whitney U Test (non- } \\
\text { parametric) } \\
\text { Wilcoxon Signed Ranks Test } \\
\text { (non-parametric) }\end{array}$ \\
\hline $\begin{array}{l}\text { Are there any effects of } \\
\text { vocabulary strategy } \\
\text { training on vocabulary } \\
\text { learning autonomy? } \\
\text { If so, how? }\end{array}$ & $\begin{array}{l}\text { (1) Pre and Post Learner Autonomy } \\
\text { Questionnaires (adapted from Güven } \\
\text { \& Sünbül, 2007); } \\
\text { (2) Post Focus Group Interview. }\end{array}$ & $\begin{array}{l}\text { Wilcoxon Signed Ranks Test } \\
\text { (non-parametric) } \\
\text { Mann Whitney U Test (non- } \\
\text { parametric) } \\
\text { Pattern Coding }\end{array}$ \\
\hline
\end{tabular}

\section{Results and Conclusion}

\section{Findings Related to the Effects of Vocabulary Strategy Training on Vocabulary Learning}

Statistically significant difference was found in post test vocabulary scores between control and experimental group, $(\mathrm{z}=-3,07, \mathrm{p}=.002)$. Post test vocabulary scores of the control group $(\mathrm{M}=11,22$, $\mathrm{SD}=4,71$ ) were significantly lower than the post vocabulary scores of the experimental group $(\mathrm{M}=22,1, \mathrm{SD}=6,6)$, which shows that vocabulary strategy training affected the vocabulary learning achievement of the students in the experimental group. Analysis of the results demonstrated statistically significant difference between pre-test and post-test vocabulary scores of the experimental group, $\mathrm{z}=-2.66, \mathrm{p}=.008$. Post-test vocabulary scores of the experimental group $(M=22.10, S D=6.67)$ were significantly higher than their pre-test vocabulary scores $(M=$ 10.10, $\mathrm{SD}=4.09$ ) (see Table 2).

Table 2. The difference between the pre and post vocabulary scores within the control and the experimental group.

\section{Wilcoxon Signed Ranks Test}

\section{Ranks}




\begin{tabular}{|ll|c|c|c|}
\hline GROUP & N & Mean Rank & Sum of Ranks \\
\hline Control POSTVOCAB-PREVOCAB & Negative Ranks & $4^{\mathrm{a}}$ & 4,00 & 16,00 \\
& Positive Ranks & $4^{\mathrm{b}}$ & 5,00 & 20,00 \\
& Ties & $1^{\mathrm{c}}$ & & \\
& Total & 9 & & \\
\hline Experimental POSTVOCAB-PREVOCAB Negative Ranks & $1^{\mathrm{a}}$ & 1,50 & 1,50 \\
& Positive Ranks & $9^{\mathrm{b}}$ & 5,94 & 53,50 \\
& Ties & $0^{\mathrm{c}}$ & & \\
& Total & 10 & & \\
\hline
\end{tabular}
a. POSTVOCAB $<$ PREVOCAB
b. POSTVOCAB $>$ PREVOCAB
c. $P O S T V O C A B=P R E V O C A B$

\section{Test Statistics}

\begin{tabular}{|l|c|}
\hline GROUP & $\begin{array}{c}\text { POSTVOCAB- } \\
\text { PREVOCAB }\end{array}$ \\
\hline Control Z Z & $-289^{\mathrm{a}}$ \\
Asymp. Sig. (2-tailed) &, 773 \\
\hline Experimental Z & $-2,657^{\mathrm{a}}$ \\
Asymp. Sig. (2-tailed) &, 008 \\
\hline
\end{tabular}

a. Based on negative ranks

b. Wilcoxon Signed Ranks Test

The post interview and think aloud protocol results were also found consistent with the outcomes of the statistical analyses.

\section{Findings Related to the Effects of Vocabulary Strategy Training on Learner Autonomy}

As for the effects of vocabulary strategy training on learner autonomy, there was statistically no significant difference between the pre $(M=3.95$, SD) and post autonomy scores $(M d=3,74)$ in the control group, which received no vocabulary strategy training. However, a difference between the pre $(\mathrm{Md}=3.79)$ and the post autonomy scores $(\mathrm{Md}=3.87)$ in the experimental group was obtained, although it was not very significant. The comparison of the learner autonomy scores within the control and within the experimental group are recorded in table 3.

Table 3. The Results of the Wilcoxon Signed Ranks Test showing the difference within the groups in pre and post learner autonomy questionnaires.

\section{Descriptive Statistics}

\begin{tabular}{|c|c|c|c|c|c|}
\hline \multicolumn{2}{|c|}{ Group } & \multirow{2}{*}{$N$} & \multicolumn{3}{c|}{ Percentiles } \\
\cline { 3 - 6 } & & 25 th & 50th (Median) & $7^{\text {th }}$ \\
\hline \multirow{3}{*}{ control } & Preautmean & 9 & 3.5789 & 3.9474 & 4.0526 \\
\cline { 2 - 6 } & Postautmean & 9 & 3.4211 & 3.7368 & 4.1053 \\
\hline \multirow{2}{*}{ experimental } & Preautmean & 10 & 3.3158 & 3.7895 & 4.0132 \\
\cline { 2 - 6 } & Postautmean & 10 & 3.5263 & 3.8684 & 4.0921 \\
\hline
\end{tabular}


Test Statistics ${ }^{c}$

\begin{tabular}{|c|c|c|}
\hline \multirow{2}{*}{ control } & $\mathrm{Z}$ & postautmean - preautmean \\
\cline { 2 - 3 } & Asymp. Sig. (2-tailed) & $-.676^{\mathrm{a}}$ \\
\hline \multirow{2}{*}{ experimental } & $\mathrm{Z}$ & .499 \\
\cline { 2 - 3 } & Asymp. Sig. (2-tailed) & $-.510^{\mathrm{b}}$ \\
\hline
\end{tabular}
a. Based on positive ranks.
b. Based on negative ranks.
c. Wilcoxon Signed Ranks Test

The post interview results dedicated to finding insights into the effects of vocabulary strategy training on learner autonomy revealed the following codes:
a) feeling more secure with vocabulary learning;
b) raised awareness;
c) learners' improving their problem solving skills;
d) determining the direction of their own learning;
e) more engagement in their lessons.

\section{Conclusion}

The present study is based upon methodological triangulation, which refers to the use of more than one method to gather data. The findings of the present study are important in terms of research methodology and context.

a) The findings are important methodologically as the researcher found that the use of different data collection methods had a lot of advantages in respect of providing valuable results, complementing each other with their methodological strengths. To be more specific, the pre interview results helped the researcher to draw a picture of the participants' strategy choices in detail, and to decide upon the design of the strategy training. The pre and post learner autonomy questionnaire results helped the researcher to see the effects of the treatment on learner autonomy. The post vocabulary test scores of the experimental group students, who received vocabulary strategy training, outperformed the scores of the control group students who received no special treatment and this showed that vocabulary strategy training sessions contributed to the success of the experimental group students. The think aloud protocol sessions, conducted with the control and experimental groups in the present study, served as a very effective tool to understand the mental processing of the learners, the type of the strategies the students employed to recall and learn the target words. The results of the think aloud protocols indicated a high use of vocabulary learning strategies by the experimental group students. Also, post focus group interviews conducted with the experimental group students provided the researcher with a clear picture of the effects of the strategy training on vocabulary learning achievement and learner autonomy. To sum up, quantitative data obtained in the present study concurs with the results of the data collected qualitatively, which makes the results much stronger and more reliable, in respect to the first research question, namely, "What are the effects of vocabulary strategy training on vocabulary learning?" and the second research question, namely, "What are the effects of vocabulary strategy training on vocabulary learning autonomy? If so, how?”.

b) The findings of the present study are also important in terms of context, as well since there are only a few studies dedicated to investigating the effects of vocabulary strategy training on vocabulary learning and learner autonomy in Turkey. 


\section{Strengths and Contributions of the Present Study}

The present study has contributed to the literature in following ways. The first contribution is "the context difference" due to the fact that there have been only a few studies where vocabulary strategy training is conducted in Turkey. "The authenticity of the subject" is also an important contribution to the literature, as there have been only limited studies to investigate the effects of vocabulary strategy training on vocabulary learning achievement and learner autonomy. The present study has made "methodological contributions" to the literature as a multi method approach was used. Another contribution of the present study in terms of its methodological aspects is that the think aloud method has been used in only a few earlier studies to investigate the effects of vocabulary strategy training on vocabulary learning.

\section{Limitations}

The present study is not without its limitations. The first limitation is regarding the small size of the group. Due to the fact that there were not many available classes at the preparatory school, the results obtained may not be generalizable to other contexts. The other limitation derives from the duration of the strategy training. The treatment, that is the vocabulary strategy training conducted in the present study, lasted for 3 weeks. The shortage of the treatment phase was due to the constraints of the policy of the university where the experiment took place.

\section{Implications and Suggestions for Further Research}

The present study has been an inquiry to investigate the effects of vocabulary strategy training on vocabulary achievement and vocabulary learner autonomy. Taking the significant effects of vocabulary strategy training on vocabulary learning, other studies may be carried out to investigate the relationship between reading strategies and vocabulary strategies. A study might also be considered to explore the effects of reading strategy instruction on vocabulary learning.

As mentioned in 'The Limitations Section', the length of vocabulary strategy training might have to be longer than 4 weeks in order to obtain more significant and long lasting results. Finally, taking the positive effects of strategy training on different languge skills into account, a study measuring the effects of strategy training -as a part of a curriculum- on learner autonomy and success might be considered for further research. 


\section{REFERENCES}

Cohen, A. D., \& Aphek, E. (1981). Easifying second language learning. Sudies in Second Language Acquisition, 3 (2), 221-36. In Ghazal, L. (2007). Learning Vocabulary in EFL Contexts Through Vocabulary Learning Strategies. Retrieved from http://novitasroyal.org/Ghazal.pdf

Cohen, A. D. (2003). Strategy-based learning of speech acts: developing and evaluating a web-based curriculum. Paper presented at the Independent Language Learning Conference, The Open University, Milton Keynes, UK, 5th December 2003. Retrieved from http://www.cal.org/resources/digest/digest_pdfs/ 0302cohen.pdf

Dickinson, L. (1993). Talking Shop: Aspects of Autonomous Learning. ELT Journal, 47(4), 39-56. Oxford.

Ellis, R. (1994). The study of second language acquisition. Oxford: Oxford University Press.

Foster, R. L. (1997). Addressing epistemologic and practical issues in multimethod research: a procedure for conceptual triangulation. Advances in Nursing Science, 20(2), 1-12. Lippincott.

Güven, Z. Z., \& Sünbül, M. A. (2007). The Relation between the Learners' Autonomy Levels and their Learning Styles. Dublin.

Hedge, T. (2001). Teaching and Learning in the Language Classroom. Hong Kong: Oxford University Press.

Holec, H. (1981). Autonomy in Foreign Language Learning. Oxford: Pergamon.

Hulstijn, J. H. (1993). When do foreign-language readers look up the meaning of unfamiliar words? The Influence of Task and Learner Variables. The Modern Language Journal, 77, 139-147. In Ghazal, L. (2007). Learning Vocabulary in EFL Contexts Through Vocabulary Learning Strategies. Royal 1(2), 84-91.

Little, D. (1991). Learner Autonomy. 1: Definitions, Issues and Problems. Dublin: Authentik.

Marefat, H., \& Shirazi, M. A. (2003). The Impact of Teaching Direct Learning Strategies on the Retention of Vocabulary By EFL Learners: The Reading Matrix Vol. 3. no. 2, September 2003. Retrieved from http://www.readingmatrix.com/articles/marefat_shirazi/article.pdf

Nation, I. S. P. (1990). Teaching and Learning Vocabulary. New York: Newbury House.

O'Malley, J. M., \& Chamot, A. U. (1990). Learning Strategies in Second Language. London and New York: Longman.

Oxford, R. L. (1990a). Language learning strategies and beyond: A look at strategies in the context of styles. Ed. S. S. Magnan. Shifting the instructional focus to the learner, 35-55. Middlebury, VT: Northeast Conference on the Teaching of Foreign Languages. Rubin, J. (1975). What the "good language learner" can teach us. TESOL Quarterly, 9, 41-51.

Schmitt, N. (1997). Vocabulary learning strategies. Ed. Schmitt, N., \& McCarthy, 199-227. Acquisition. Cambridge, England: Cambridge University Press.

Thanasoulas, D. (2000). What is Learner Autonomy and How can it Be Fostered. Retrieved from http:// iteslj.org/Articles/Thanasoulas-Autonomy.html

Vann, R. J., \& Abraham, R. (1990). Strategies of unsuccessful language learners. TESOL Quarterly, 24, 99-177.

Wenden, A., \& Rubin, J.(1987). Learner Strategies in Language Learning. Englewood Cliffs: PrenticeHall International.

Wenden, A. L. (1991). Learner Strategies in Language Learning. Englewood Cliffs, NJ: Prentice Hall.

Williams, M., \& Burden, R. L. (1997). Psychology for Language Teachers: A Social Constructivist Approach. Cambridge: Cambridge University Press. 